\title{
The Determinants of Retail Pharmacists Retention With a Mediating Effect of Continuance Commitment
}

\author{
Izzati Azmi (Corresponding Author) \\ Faculty of Business Management \\ University Teknologi Mara \\ Shah Alam, Selangor \\ E-mail: zatinur38@gmail.com
}

\author{
Sharizan Sharkawi \\ Faculty of Business Management \\ University Teknologi Mara \\ Shah Alam, Selangor \\ E-mail: sharizan_sharkawi@uitm.edu.my
}

Nor Intan Adha

Faculty of Business Management

University Teknologi Mara

Shah Alam, Selangor

E-mail: intan520@uitm.edu.my

Received: June 24, 2019 Accepted: July 18, 2019 Online published: August 6, 2019 doi:10.5296/ijhrs.v9i3.14969

URL: https://doi.org/10.5296/ijhrs.v9i3.14969

\begin{abstract}
The turnover of employees is the most challenging issue facing by the organization. Retail pharmacy industry in Malaysia is also facing the same issue, especially for pharmacist position. According to the interview conducted with one of the biggest retail pharmacies in Malaysia, in $2018,20 \%$ of their pharmacists resigned and reluctant to stay even they were
\end{abstract}


offered with a higher salary or better benefits. A skilled and experienced pharmacist is very important in a pharmacy and any other health care center because they are dealing with a patient's health and safety. Newly graduate pharmacist might cause medication errors and increase the risk of patient's safety. 155 pharmacists will be selected for this study. The sample for this study is the retail pharmacist who works in Negeri Sembilan and Pahang state. This research will focus to identify which factors (transformational leadership, job satisfaction, and procedural justice) have the most significant influences on a retail pharmacist's retention. In addition, this study will also investigate a mediating effect of continuance commitment towards the independent and dependent variables. The descriptive research design will be used as the structure of this research. This study will use the established instruments from the relevant research journal instead of developing own questions. The collected data and information from the respondents will be analyzed by using SPSS software.

Keywords: employee retention, transformational leadership, job satisfaction, procedural justice, continuance commitment, retail pharmacist

\section{Introduction}

Nowadays, most of the organizations have become a technology-driven company because of the evolution of technology in the market (Kossivi, Xu, \& Kalgora, 2016). Nevertheless, this phenomenon does not affect the importance of employees in an organization because the technology still needs assistance from an employee. There are a few definitions of employee retention among researchers. According to Das and Baruah (2013), employee retention is focused on sustaining and influencing employees to stay in an organization for a long period of time or involved with a procedure in which the employees are inspired to stay until the project is completed. On the other hand, Mehta, Kurbetti, and Dhankhar (2014) stated that employee retention is a strategy adopted by organizations to sustain valuable employees and at the same time reaching their operational needs. It can be concluded that the retention of valuable employees is a crucial concern in which organizations need to fulfill in order to succeed in the competitive market nowadays.

There are a few previous studies that investigate the determinants of employee retention in Malaysia. Some of the determinants of employee retention among Malaysian workers are job burnout, job satisfaction, pay satisfaction, and commitment (Lam, Law, Loo, Ng, \& Ooi, 2015; Nagarajan, \& Thangavelu, 2016). There seemed to be several gaps in employee retention studies. Firstly, the determinants for employee retention studies are repeating and more focusing on external factors rather than internal factors. In addition, there are numbers of common studies are more focused on the nursing industry, banking industry and public sector (Lam, Law, Loo, Ng, \& Ooi, 2015; Nagarajan, \& Thangavelu, 2016; Mansor, \& Idris, 2015; Izard-Carroll, 2016; Asiah, 2018). The studies regarding employee retention among retail pharmacist are still limited. Because of the lack of research study in the retail pharmacy industry, this research will be conducted to identify the major factor of retail pharmacist's retention in Malaysia.

This study is essential because the expansion of retail pharmacy is predicted to increase 
extraordinarily in the coming years. In addition, the government has recognized healthcare industry including pharmacy as one of the National Key Economic Area to achieve a high-income country status in 2020 ("Market Review on Priority Sector Under Competition Act 2010 Pharmaceutical Sector," 2017). Thus, the retention of experience and skills pharmacist indirectly can help to expand the retail pharmacy industry in Malaysia.

Besides that, Mohamad, Asrul, and Chua (2013) stated that nearly 30\% of the consumer in Malaysia required long-term medication because of chronic diseases. The National Survey on the Use of Medicine (2013) also stated that more than $70 \%$ of consumers buy their medications from retail pharmacies (Mohamad, Asrul, \& Chua, 2013). Thus, the retention of the experienced and senior retail pharmacist is very crucial to ensure medication safety among consumers or patients. According to Siti, Tan, and Doris (2016) medication errors are common among discharge prescriptions especially during after office hour due to high turnover rate and understaffed., this situation is preventable if the pharmacy has a sufficient number of the pharmacist because the prescriptions can be rectified by the pharmacist before dispensing the medications to the patients (Siti, Tan, \& Doris, 2016).

The purpose of this quantitative study with a descriptive research design is to identify the relationship between transformational leadership, job satisfaction, procedural justice and employee retention among retail pharmacist. This study will involve 155 respondents who work in the retail pharmacy located in Negeri Sembilan and Pahang. These two states will be selected to make comparisons of the findings between two different states which is the southern (Negeri Sembilan) and the east (Pahang State) of Malaysia. The objective of this study is to provide information to employers within the retail pharmacy industry regarding the factor of retail pharmacy retention in Malaysia. The process of achieving this objective will include seeking the answers to the following questions:

RQ1: What are the factors that have an influence on retail pharmacist's retention?

RQ2: Which relationship will be most affected by continuance commitment?

\section{Literature Review}

\subsection{Retail Pharmacist}

The pharmacist is an advisor that supply medicines with a prescription or they can sell without a prescription when legally permitted and they continue links with other health care professional in primary health care (Hassali, Awaisu, Shafie, \& Saeed, 2009). According to Thamby and Subramani (2014), the pharmacist is an individual who produced formulation, supply and gives clinical advice or information about drugs or medications to healthcare professionals and patients. Retail pharmacist is one of the health care professionals who are most accessible to society (World Health Organization, 1994). This is because a retail pharmacist works in the retail pharmacy which is close to the society. The retail pharmacist is responsible to provide clear counseling to the patients at the time of dispensing the prescription or non-prescription medicines and provide drugs information to the other health care professional (World Health Organization, 1994). The greater involvement of retail pharmacist in the self-care, the greater their responsibility and accountability towards patients 
(World Health Organization, 1998). The retail pharmacist will have more engagement with the patients compared to the pharmacist in the hospital. This is because the patient will communicate directly with the pharmacist in order to solve their health problem.

\subsection{Employee Retention}

Employee retention is the ability and power of an organization to keep and maintain the valuable and talented employees longer in the organization or avoiding employees leaving the organization for the competitors (Johnson, 2000). In addition, it also involved an employee's voluntary actions to stay in the organization which affected by the organization's environment that has been created for a long time (Ng'ethe, Iravo, \& Namusonge, 2012). The employee retention is very crucial because it can increase organizational profit, achieve organizational goals and at the same time, it can cut a high cost of recruitment and training for the newly hired employees (Oladapo, 2014). Based on Lee (2012), Executive Director of Malaysia Employer Federation has stated that the cost for employee replacement is huge which will cost around RM 25,000 to RM 30,000 to replace the resigned employee (Koh, 2018). According to the previous studies, some of the external determinants of employee retention among Malaysian worker are included human resources practices, communication, supervisor support, training opportunities, and career development support (Lam, Law, Loo, Ng, \& Ooi, 2015; Nagarajan, \& Thangavelu, 2016). On the other hand, the example of internal factors which can affect the Malaysian worker's retention are job burnout, job satisfaction, pay satisfaction, and commitment (Lam, Law, Loo, Ng, \& Ooi, 2015; Nagarajan, \& Thangavelu, 2016).

\subsection{Transformational Leadership}

In 1978, James Macgregor Burns was the first person who had introduced the concept of transformational leadership in his descriptive research on political leaders (Jung \& Sosik, 2002). Transformational leadership is focused on the growth of the fullest potential of individuals and their motivation on the greater good versus their own self-interest for the sake of the organization (Middleton, Harvey, \& Esaki, 2015). According to Northouse (2007), transformational leadership can be divided into four aspects:

a) Idealized Influence is the leader's capability to deliver a vision to the followers, to obtain trust and respect, and to inspire faith in followers. A leader who indicated idealized influence showed a high standard of moral conduct and ethical. In other words, the leader does not use power for personal gain

b) Inspiration Motivation is the leader's capability to motivate, inspire, and encourage followers.

c) Intellectually Stimulating leader inspires the followers to identify their own values and beliefs. The leader highlights problem-solving and encourages intelligence and rationality. In addition, the leader will stimulate followers to think differently and try new approaches. $\mathrm{He} / \mathrm{she}$ will not criticize followers when they differ from the leader's ideas.

d) Individualized Consideration is a leader who provides a supportive environment for his/her 
followers. This leader will provide personal attention to each follower through coaching, treating, and advising every follower individually. In addition, the leader will also give continuous follow-up and feedback and treat their followers with respect. Besides that, this type of leader will align follower's needs with organizational objectives and goals.

This type of leadership style adequately explains the connection between leadership and employee retention since employees have a tendency to stay in an organization where they are feel attached and comfortable (Mwita, Mwakasangula, \& Tefurukwa, 2018).

\subsection{Job Satisfaction}

Weiss (1999) defined job satisfaction as the work judgment by the employees positively or negatively. On the other hand, Buitendach and Rothmann (2009) mentioned that job satisfaction is involved employee's emotional reaction about the works. Job satisfaction is an employee's judgment on how good their jobs and how to fit the employee with the organization (Pool \& Pool, 2007). In addition, it also indicates how employees enjoy their works (Pool \& Pool, 2007). According to the previous study, both job content and job security are found to influence the overall employee's job satisfaction (Behera, Sahoo, \& Sundaray, 2011). Employees feel enjoyed when they performing jobs that involve higher levels of skills and knowledge (Guthrie, 2001). Besides that, employees also will feel satisfied when they taking a job that is related to decision-making and at the same time they are provided with a certain degree of freedom in carrying out their tasks (Guthrie, 2001). Job satisfaction in the organization can be measured by the employee retention rate in the organization (Nadeem, 2010). If the level of employee's job satisfaction high, employee retention rate will increase as well (Nadeem, 2010). On the other hand, Ellickson and Logsdon (2002) found that employee's job satisfaction can lead to high productivity, organizational commitment, minimize the absenteeism and the most important is it can reduce employee's turnover rate.

\subsection{Procedural Justice}

Organizational justice is involved in how leaders produce or use procedures that are fair to all party (Colquitt, Conlon, Wesson, Porter, \& Ng, 2001). There are three dimensions of organizational justice that have been identified by Theorist Greenberg (1987) and Bies and Moag (1986) that is procedural justice, distributive justice, and interactional justice. According to Thibaut and Walker (1975), procedural justice is about the fairness of the process and followed by authority figures in the organization to allocate resources and outcomes. On the other hand, Moorman (1991) stated that procedural justice describes the extent to which employees identify that the outcome allocation decisions were fairly made according to the organization's formal procedures and treatment given to implement the procedures. Procedural justice also being described as the fairness of procedures used in decision-making about bonuses, advancement and performance appraisal in an organization (Roch \& Shanock, 2006). Leventhal (1980) stated that there are six fairness criteria in procedural justice perceptions: bias suppression, ethicality, consistency, representativeness, and correctability (Gul, Rehman, Usman, Hussain, 2015). Tyler (2006) stated that procedural justice plays an essential role in encouraging employee compliance with the law. Other than 
that, one of the strongest components of procedural justice is a voice which is when those who are affected by the decision are given the opportunity to voice out their opinions or preferences, their perception about justice on decisions and outcomes will high (Gürbüz \& Mert, 2009). Thus, this situation will increase their tendency to remain in the organization.

\subsection{Continuance Commitment}

Continuance commitment is one of the components in organizational commitment (Meyer \& Ellen, 1997). In general, continuance commitment is defined as an employee's willingness to remain in an organization because of personal investment which is untransferable investment such as good working relationship with colleagues, retirement or career investment, unique acquired job skills, years of employment, and other benefit that make it too costly for employee to leave and seek employment in the other organization (Umoh, Amah \& Wokocha, 2014). Continuance commitment is an employee's awareness about the cost associated when leaving the organization (Meyer \& Ellen, 1997). The risk and cost involved are calculative in nature (Meyer \& Ellen, 1997). Besides that, because of the fear of losing investment, individuals increase continuance commitment because of a perceived lack of alternatives (Umoh et al., 2014). Thus, continuance commitment involves a measurement between the cost of leaving and the benefits of staying (Umoh et al., 2014). It supports the arguments from Meyer and Ellen (1984) which is continuance commitment involves personal investment appraisal that links with a person's current employment and the availability of employment alternatives. When employees have a high level of continuance commitment, they will maintain their current employment because it provides them with a desirable personal need that they are reluctant to sacrifice or because they perceived a lack of employment alternatives elsewhere (Umoh et al., 2014).

\subsection{The Conceptual Framework}

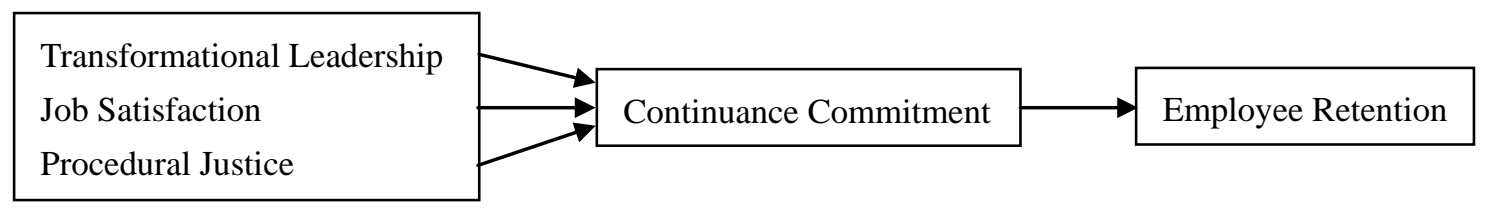

Figure 2.1. Conceptual Framework for The Determinants of Retail Pharmacists Retention with a Mediating Effect of Continuance Commitment

Figure 2.1 shows the conceptual framework proposed for this study. This framework proposed that the three dimensions which are transformational leadership, job satisfaction, procedural justice have influenced on employee retention while continuance commitment will be a mediating factor between independent and dependent variables. Before select the independent variables and mediator for the study, the researcher has conducted an interview session with the respondents to understand and identify the real situation that happened in the retail pharmacy. Besides that, the interview was conducted to ensure the chosen variables are suitable for the current situation and selected sample.

In order to justify the selection of the variables, the researcher has reviewed the past literature to identify the relationship between the selected variables. The conceptual framework 
indicates that the strength of the relationship between transformational leadership, job satisfaction, procedural justice, and employee retention will be affected by the continuance commitment. These elements will be investigated by distributing the questionnaire to the respondents in the effort to obtain the information or point of view with regards to this study. It is hoped the finding of this study will bring a new perspective on the determinants of retail pharmacists retention in Malaysia.

\section{Methodology}

\subsection{Research Design}

This study will use a quantitative method to collect and analyze the data. This is because it will be more clear to make a prediction on a numerical basis. Thus, the researcher will choose a descriptive research design. The descriptive research is used to examine and collect information on particular issues in society, group or individual (Akhthar, 2016). The research instruments for this study consist of a self-administered questionnaire. This questionnaire will be served as primary data for this study. The questions will be prepared in the English language and close-ended questions. Besides that, the Five-Likert scale will be used as the answer to the questions of Section B, C, and D in this study.

\subsection{Measurement}

The items in the questionnaire for this study will be adopted and adapted from different researchers, include Avolio, Bass, and Jung, (1995); Moyes and Redd (2008); Niehoff and Moorman (1993); Allen and Meyer (1990); and Kyndt, Dochy, Michielsen, and Moeyaert (2009). The questionnaire consists of four sections. Section A will be used to measure the demographic information while Section B, C, and D will collect the data and information about the independent, mediator, and dependent variables in this study. The Five-Likert scale will be used for Section B, C, and D in this study. The Likert scale is ranging from strongly disagree to strongly agree.

\subsection{Sampling}

The sample for this study is the pharmacist who works at a retail pharmacy in Negeri Sembilan and Pahang state to make comparisons of the findings between two different states which is the southern (Negeri Sembilan) and the east (Pahang State) of Malaysia. However, this study will not include the pharmacist who is self-employed or works at their own retail pharmacy. Since the number of population for this study is known, Table Krejcie and Morgan (1970) will be used to identify the sample size of the study. By referring to Table Krejcie and Morgan (1970), this study will select 155 respondents from Negeri Sembilan and Pahang state. Because the respondents of this study come from two different states, the stratified sampling technique will be used to ensure the selected number of respondents representing the population of each state. In addition, simple random sampling will be used in this study. This study will list all the respondent's name (by referring to the Pharmaceutical Service Programme, (2019)) in the Excel file and use the random formula to make sure the respondents are randomly selected. 


\subsection{Data Analysis}

This study will use the SPSS (Statistical Package for the Social Sciences) software to conduct the data analysis. The descriptive, Pearson correlation, reliability, and multiple regression analysis will be conducted for this study. The descriptive analysis will be used to summarize the collected data in a tabular form, percentage, and frequencies. Meanwhile, the Pearson correlation analysis will identify the relationship between the variables in this study. The reliability analysis will measure the internal consistency or the strength of association between variables. Lastly, the multiple regression will identify the influence or relationship for each variable and also will identify the mediating effect of continuance commitment in this study.

\section{Conclusion}

The researcher started this study because of the concern on the turnover rate among the retail pharmacist in Malaysia. There is a requirement to get a better understanding about the factors of retail pharmacists retention in Malaysia. Their position is sometimes viewed negligently by the society or company but in reality, they play essential roles by ensuring the health and safety among patients and the community. It is then our responsibility to give awareness to the employer by revealing the real situation happened in the retail pharmacy. The researcher found that many important studies have investigated the determinants of employee retention among Malaysian workers but the study regarding the factors of retail pharmacist retention is still limited. The new findings and theories from this study will be developed by aligning with the current event. It is hoped the finding of this study will bring a new perspective on the determinants of retail pharmacists retention and provide valuable idea and information to the academic and practitioner within the same field.

\section{Acknowledgement}

We would like to acknowledge everyone who played a role in this study. We also sincerely thank our supervisors for guidance and encouragement to complete this study.

\section{References}

Akhthar, M. I. (2016). Research Design. 68-84. https://doi.org/10.2139/ssrn.2862445

Allen, N. J., \& Meyer, J. P. (1990). The measurement and antecedents of affective, continuance and normative commitment to the organization. Journal of occupational psychology, 63(1), 1-18. https://doi.org/10.1111/j.2044-8325.1990.tb00506.x

Asiah, A. (2018). The Factors that Influence Employee Retention and its Impact on Organizational Citizenship Behavior and Job Embeddedness: A Study at the Public Sector Organizations in Malaysia.

Avolio, B. J., Bass, B. M., \& Jung, D. I. (1995). Multifactor Leadership Questionnaire. Redwood City, CA: Mind Garden.

Behera, N., Sahoo, C. K., \& Sundaray, B. K. (2011). Retaining high performing employees through job satisfaction: A theoretical construct. 
Bies, R. J., \& Moag, J. F. (1986) Interactional Justice: Communication Criteria of Fairness. In: Lewicki, R.J., Sheppard, B.H. and Bazerman, M.H., Eds. Research on Negotiations in Organizations, 1, 43-55.

Buitendach, J. H., \& Rothmann, S. (2009). The validation of the Minnesota Job Satisfaction Questionnaire in selected organisations in South Africa. SA Journal of Human Resource Management, 7(1), 1-8. https://doi.org/10.4102/sajhrm.v7i1.183

Colquitt, J. A., Conlon, D. E., Wesson, M. J., Porter, C. O., \& Ng, K. Y. (2001). Justice at the millennium: a meta-analytic review of 25 years of organizational justice research. Journal of applied psychology, 86(3), 425. https://doi.org/10.1037/0021-9010.86.3.425

Das, B. L., \& Baruah, M. (2013). Employee retention: A review of literature. Journal of Business and Management, 14(2), 8-16. https://doi.org/10.9790/487X-1420816

Ellickson, M. C., \& Logsdon, K. (2002). Determinants of job satisfaction of municipal government employees. Public Personnel Management, 31(3), 343-358. https://doi.org/10.1177/009102600203100307

Greenberg, J. (1987). A taxonomy of organizational justice theories. Academy of Management review, 12(1), 9-22. https://doi.org/10.5465/amr.1987.4306437

Gul, H., Rehman, Z., Usman, M., \& Hussain, S. (2015). The Effect of Organizational Justice on Employee Turnover Intention with the Mediating role of Emotional Exhaustion in the Banking Sector of Afghanistan. International Journal of Management Sciences, 5(4), 272-285.

Gürbüz, S., \& Mert, I. S. (2009). Validity and Reliability Tests of Organizational Justice Scale: An Empirical Study in a Public Organization. 3(3), 137-162.

Guthrie, J. P. (2001). High-involvement work practices, turnover, and productivity: Evidence from New Zealand. Academy of management Journal,44(1), 180-190. https://doi.org/10.2307/3069345

Hassali, M. A. A., Shafie, A. A., See, O. G., \& Wong, Z. Y. (2016). Pharmacy practice in Malaysia. In Pharmacy Practice in Developing Countries (pp. 23-40). Academic Press. https://doi.org/10.1016/B978-0-12-801714-2.00002-2

Izard-Carroll, M. D. (2016). Public sector leaders' strategies to improve employee retention.

Johnson, M. (2000) Winning the People Wars: Talent and the Battle for Human Capital: Financial Times Management

Jung, D. I., \& Sosik, J. J. (2002). Transformational leadership in work groups: The role of empowerment, cohesiveness, and collective-efficacy on perceived group performance. Small group research, 33(3), 313-336. https://doi.org/10.1177/10496402033003002

Koh, Y. H. (2018). Factors Affecting the Retention of Generation Y Workers in Food Industry (Doctoral dissertation, UTAR). 
Kossivi, B., Xu, M., \& Kalgora, B. (2016). Study on determining factors of employee retention. Open Journal of Social $\quad$ Sciences, 4(05), 261. https://doi.org/10.4236/jss.2016.45029

Krejcie, R. V., \& Morgan, D. W. (1970). Determining sample size for research activities. Educational and psychological measurement, 30(3), 607-610. https://doi.org/10.1177/001316447003000308

Kyndt, E., Dochy, F., Michielsen, M., \& Moeyaert, B. (2009). Employee Retention: Organisational and Personal Perspectives. Vocations and Learning, 2(3), 195-215. https://doi.org/10.1007/s12186-009-9024-7

Lam, C. L., Law, S. F., Loo, Y. J., Ng, W. Y., \& Ooi, S. L. (2015). A study on factors affecting employee retention in nursing industry at Klang Valley (Doctoral dissertation, UTAR).

Mansor, M., \& Idris, A. (2015). Employee retention in the Malaysian banking industry: Do flexible practices work?. South African Journal of Business Management, 46(1), 1-9. https://doi.org/10.4102/sajbm.v46i1.78

Market Review on Priority Sector Under Competition Act 2010 Pharmaceutical Sector. (2017). Malaysia Competition Commission (MyCC), 28-40.

Mehta, M., Kurbetti, A., \& Dhankhar, R. (2014). Study on Employee Retention and Commitment. International Journal of Advance Research in Computer Science and Management Studies, 2(2), 154 - 164.

Meyer, J. P. \& Allen, N. J. (1997). Advanced Topics in Organizational Behavior: Commitment in the workplace: Theory, research, and applicationThousand Oaks, CA: SAGE Publications, Inc.

Meyer, J. P., \& Allen, N. J. (1984). Testing the" side-bet theory" of organizational commitment: Some methodological considerations. Journal of applied psychology,69(3), 372. https://doi.org/10.1037/0021-9010.69.3.372

Middleton, J., Harvey, S., \& Esaki, N. (2015). Transformational leadership and organizational change: how do leaders approach trauma-informed organizational change... twice?. Families in Society, 96(3), 155-163. https://doi.org/10.1606/1044-3894.2015.96.21

Mohamad, A. H., Asrul, A. S., \& Chua, G. N. (2013). A National Survey on the Use of Medicines (Nsum) by Malaysian Consumers. Ministry of Health Malaysia.

Moorman, R. H. (1991). Relationship between organizational justice and organizational citizenship behaviors: do fairness perceptions influence employee citizenship?. Journal of applied psychology, 76(6), 845. https://doi.org/10.1037/0021-9010.76.6.845

Moyes, G. D., \& Redd, T. C. (2008). Empirical analysis of factors influencing the level of job satisfaction of Caucasian and Hispanic accounting professionals. International Business \& Economics Research Journal, 7(10), 21-42. https://doi.org/10.19030/iber.v7i10.3298 


\section{Ml Macrothink}

International Journal of Human Resource Studies

ISSN 2162-3058

2019, Vol. 9, No. 3

Mwita, K. M., Mwakasangula, E., \& Tefurukwa, O. (2018). The Influence of Leadership on Employee Retention in Tanzania Commercial Banks. International Journal of Human Resource Studies, 8(2). https://doi.org/10.5296/ijhrs.v8i2.12922

Nadeem, M. (2010). Role of training in determining the employee corporate behavior with respect to organizational productivity: Developing and proposing a conceptual model. International Journal of Business and Management, 5(12), 206-211. https://doi.org/10.5539/ijbm.v5n12p206

Nagarajan, A., \& Thangavelu, L. (2016). Talent Retention Strategies, Organizational Commitment and Intention to Stay in Commercial Banks in Malaysia: The Moderating Role of Person-organization Fit.

Ng'ethe, J. M., Iravo, M. E., \& Namusonge, G. S. (2012). Determinants of academic staff retention in public universities in Kenya: Empirical review. International Journal of Humanities and Social Sciences, 2(13), 205-212.

Niehoff, B. P., \& Moorman, R. H. (1993). Justice as a mediator of the relationship between methods of monitoring and organizational citizenship behavior. Academy of Management journal, 36(3), 527-556. https://doi.org/10.2307/256591

Northouse, P. G. (2007). Leadership: Theory and Practice $\left(4^{\text {th }}\right.$. ed.). London: SAGE

Oladapo, V. (2014). The impact of talent management on retention. Journal of Business Studies Quarterly, 5(3), 19-36.

Pharmaceutical Service Programme. (2019). Register of License. Retrieved June 19, 2019, from https://www.pharmacy.gov.my/v2/en/information/register-licences.html

Pool, S., \& Pool, B. (2007). A management development model: Measuring organizational commitment and its impact on job satisfaction among executives in a learning organization. Journal of Management Development, 26(4), 353-369. https://doi.org/10.2307/256591

Roch, S. G., \& Shanock, L. R. (2006). Organizational Justice in an Exchange Framework: Clarifying Organizational Justice Distinctions. Journal of Management, 32(2), 299-322. https://doi.org/10.1177/0149206305280115

Siti, Q., Tan, X. F., \& Doris, G. (2016). A comparison Study on the Prescribing Error in Discharge Presription from Medical Ward in a Regional Referral Hospital. Malaysia Journal of Pharmacy, 2(2), 13

Thamby, S. A., \& Subramani, P. (2014). Seven-Star Pharmacist Concept by World Health Organization. Journal of Young Pharmacists, 6(2). https://doi.org/10.5530/jyp.2014.2.1

Thibaut, J. W., \& Walker, L. (1975). Procedural justice: A psychological analysis. Hillsdale, NJ: Erlbaum.

Umoh, G. I., Amah E., \& Wokocha, I. H. (2014). Employee Benefits and Continuance Commitment in the Nigerian Manufacturing Industry. Journal of Business and Management, 16(2), 69-74. https://doi.org/10.9790/487X-16226268 


\section{Macrothink}

International Journal of Human Resource Studies

ISSN 2162-3058 2019, Vol. 9, No. 3

Weiss, E. M. (1999). Perceived workplace conditions and first-year teachers' morale, career choice commitment, and planned retention: A secondary analysis. Teaching and Teacher Education, 15(8), 861-879. https://doi.org/10.1016/S0742-051X(99)00040-2

World Health Organization. (1994). The Role of the Pharmacist in the Health Care System. $1-37$.

World Health Organization. (1998). The Role of the pharmacist in self-care and self-medication: report of the 4th WHO Consultative Group on the Role of the Pharmacist, The Hague, The Netherlands, 26-28 August 1998 (No. WHO/DAP/98.13). Geneva: World Health Organization.

\section{Copyright Disclaimer}

Copyright for this article is retained by the author(s), with first publication rights granted to the journal.

This is an open-access article distributed under the terms and conditions of the Creative Commons Attribution license (http://creativecommons.org/licenses/by/4.0/). 